\title{
Cura Personalis, Cura communitas: Loving our neighbor in Covid-19 times
}

\author{
Jonathan D. Quick ${ }^{a}$
}

${ }^{a} \mathrm{MD}, \mathrm{MPH}$, Managing Director, Pandemic Preparedness and Prevention, The Rockefeller Foundation Adjunct Professor of Global Health, Duke Global Health Institute

Author, The End of Epidemics $(2018,2020)$

The months of November and December have given chilling notice that the pandemic is far from over. Worldwide the global case rates continued steadily upward, with daily new cases exceeding 700,000 for the first time, total confirmed cases surpassing 75 million, and deaths exceeding 1.6 million. ${ }^{1}$ After pushing back or being spared by the April-May COVID-19 onslaught France, Italy, Germany, Russia, the United Kingdom, and other countries experienced record daily highs for new cases and a steady increase in the cumulative death toll. In the U.S., nearly every state experienced new daily highs for confirmed cases. ${ }^{2}$ By mid-December deaths were occurring at the rate of more than 75,000 per month. Nationwide nearly 17 million cases and more than 300,000 deaths had been reported. Parts of Latin America, North Africa, and the Middle East were also seeing new surges. With the exception of new outbreaks in India, Kenya, South Africa, Australia and a few other countries, Asia and subSaharan Africa maintained a relatively low incidence of COVD-19.

Pandemic misinformation, fatigue, denial, and resistance - along with cooler weather - have created a perfect storm for regional and national surges. ${ }^{3}$ Pandemic fatigue occurred among the many who understood the reality of COVID-19 but were tiring of the efforts needed to keep themselves and their loved ones safe. ${ }^{4,5}$ Pandemic denial continued among those convinced reports of a pandemic were untrue and that masking, distancing, and other preventive measures were an unnecessary infringement on their liberty. Finally, resistance against stringent restrictions resulted in sometimes violent protests. ${ }^{6}$

In stark contrast, the last weeks of 2020 also brought the most encouraging - some would say miraculous - news since the pandemic began: In rapid succession the world learned that the Pfizer and Moderna vaccines both had achieved over 90\% efficacy in preventing COVID-19 illness, the Oxford/Astra-Zeneca vaccine had achieved at least $70 \%$ efficacy, and several other vaccines were showing promising results. Combined production capacity of at least three billion doses added further cause for optimism. ${ }^{7}$

What should be the Christian response in the face of an out-of-control pandemic in large parts of the world, continuing vulnerabilities in other parts of the world, and the potential to immunize the world with safe, effective vaccines? As always, we turn to Jesus, who taught with carefully crafted words and inspiring deeds. Since its earliest days the church has responded to pandemics through Jesus' Great Commandment to, "love your neighbor as yourself." He made clear the practical meaning of these words thought his miracles, two-thirds of which were healings. The apostle Paul, building upon this, added "The only thing that counts [for Jesus] is faith expressing itself through love." (Galatians 5:6)

Drawing on the New Testament's framework of action motived by faith, the Catholic Jesuit 
concept of cura personalis, "care of the whole person," emphasizes dedication to the physical, psychological, and spiritual well-being of the individual. ${ }^{8,9}$ One of the most visible ways the early church exemplified this spirit was through its response to pandemics. In 260 A.D. during the height of the Cyprian Plague, the Bishop Dionysius of Corinth in his Easter Sunday message noted that,

Most of our brother Christians showed unbounded love and loyalty, never sparing themselves, and thinking only of one another. Heedless of danger, they took charge of the sick, attending to their every need and ministering to them in Christ, and with them departed this life serenely happy. ${ }^{10}$

In response to the deadliest pandemic in one hundred years, the Christian medical community around the world has responded to the current pandemic with same cura personalis, providing care for the sickest and most vulnerable, even at the cost of their own lives.

Jesus' admonition to His followers referred not only to acts of love toward individuals but also to loving our neighbors collectively through acts of cura communitas - what one might call dedication to the "care of the whole community". Martin Luther reflects this obligation in this 1527 letter, Whether One May Flee from a Deadly Plague. He writes that not only health providers, but pastors, mayors, and others in public service, "must remain steadfast before the peril of death." "The Christian Medical Commission leadership in the 1978 Alma Ata declaration and primary health care and Health for All movement that followed ${ }^{12}$ are examples of the spirit of cura communitas in action. In their dialogue on a Christian response to the current pandemic ${ }^{13}$ noted British theologian NT Wright, author of God and the Pandemic ${ }^{14}$ and U.S. National Institutes of Health Director, Dr. Francis Collins, author of The Language of $\operatorname{God}^{15}$ reflect the spirit of cura communitas.

Dec 2020. Christian Journal for Global Health 7(5)
What should cura communitas look like in the time of COVID-19? First, it requires knowing, applying, and publicly encouraging masking, distancing, and other safe living practices that have enabled entire communities and countries to bend their pandemic curve of new cases. Science that increases well-being and saves lives is one of God's greatest gifts to humanity. Yet religious leaders have been some of the most influential opponents to proven pandemic control measures. ${ }^{16}$ Religious services, weddings, and funerals around the globe have been associated with COVID-19 outbreaks, with tens to thousands of resulting infections and some deaths. ${ }^{17,18}$ The most notable, which occurred in the early days of the pandemic, was the February 9 service at the Shincheonji Church of Jesus service in South Korea that ultimately was associated with 5006 COVID-19 cases and numerous deaths. ${ }^{19}$

Speaking as both a scientist and devout Christian, Francis Collins advises,

The church, in this time of confusion, ought to be a beacon, a light on the hill, an entity that believes in truth. This is a great moment for the church to say, no matter how well intentioned someone's opinions may be, if they're not based upon fact, the church should not endorse them. ${ }^{20}$

Drawing from decades of experience in health, development and natural disasters, religious communities across the faith spectrum have actively worked to mobilize, educate, and support community responses. ${ }^{21,22}$ Christian Connections for International Health, with more than 120 organizational members from five continents, compiled COVID-19 resources for faith-based organizations $^{23}$ including country work from Nigeria $^{24}$ to Nicaragua. ${ }^{25}$

Second, with the prospect of large-scale availability SARS-CoV-2 vaccines, cura communitas commits us to support global and national commitments to action that ensures both equity of access to vaccines and widespread acceptance of vaccination. Coordinated by the 
WHO, GAVI, and CEPI, COVAX has brought together more than 180 countries with the goal of providing at least 2 billion doses of proven COVID19 vaccines to immunize the most vulnerable 20 per cent of people in 91 low and middle-income countries, mostly in Africa, Asia and Latin America. ${ }^{26}$ At the same time, inadequate funding and actions by high income countries competing for vaccine access threaten to delay access to the rest of the world. ${ }^{27}$ It is incumbent on all of us to join religious leaders in supporting to access to pandemic vaccines for the most vulnerable..$^{28,29}$

Vaccine availability must be followed by vaccine confidence and vaccination acceptance. Building on the persistent vaccine-autism myth ${ }^{30}$, a steady campaign of misinformation, and isolated examples of genuine vaccine safety issues, vaccine skeptics have mounted an aggressive campaign against SARS-CoV-2 vaccines. Some communities decline vaccination for "religious reasons", even though no major faith tradition opposes vaccination. ${ }^{31}$ In a June, 2020 global survey, the percent of respondents saying they would take a COVID-19 vaccine if "proven safe and effective and is available" varied from more than $80 \%$ in Brazil, China, South Africa and South Korea to less than $60 \%$ in France, Poland, and Russia. ${ }^{32}$ A late November survey in the U.S. found that just over $60 \%$ of whites and Latinos would be vaccinated when given the opportunity, but just $42 \%$ of black Americans, who have been hardest-hit by the pandemic, would trust the vaccine. ${ }^{33}$

Personal healthcare providers and pastors remain highly trusted sources of information and advice. $^{33,34}$ This makes it incumbent on the faithbased global health community to empathetically explore reasons for vaccine hesitation, to become fully informed on the safety and efficacy of new vaccines, ${ }^{35}$ and to champion vaccine acceptance especially for the most vulnerable individuals and communities. ${ }^{36}$ Drawing on the historical roots of this distrust, Dr. Rueben Warren of Tuskegee University describes steps clinicians, researchers,

Dec 2020. Christian Journal for Global Health 7(5) and others must take to earn and rebuild trustworthiness among black Americans. ${ }^{37}$ A recent multi-faith exploration on bridging religious divides and mobilizing religious support concluded,

Theologians, scientists, and public health specialists need to join with political and community leaders in a thoughtful conversation that builds the needed trust and respect in carefully vetted vaccines. ${ }^{28}$

Finally, in the spirit of cura communitas, even as we fight to end COVID-19 we must learn from it and take all necessary action to make the world safer from future pandemics. Through God's grace humanity has created a world with far more comforts and opportunities to flourish than our forebears enjoyed. With these benefits has come greater complexity, inter-connectedness, and vulnerability. Without vigorous preventive action we face innumerable future pandemics from an accelerating web of risk factors: urbanization, healthcare inequities, lifestyle diseases, international travel, encroachment on animal habitats, and more. ${ }^{38}$

As COVID-19 has vividly reminded us, the human and economic cost of complacent inaction is far, far greater than the cost of prevention. ${ }^{39,40}$ Scientists, public health officials, behavioral scientists, and economists know what is needed ${ }^{41}$ It remains with leaders at all levels, committed professionals and engaged citizens to press forward.

How will the Christian global health community be remembered? Surely it will be remembered for loving our neighbor through the selfless cura personalis response of Christian health workers, hospitals, and caregivers. We must strive also to be remembered for loving our neighbor through a spirit of cura communitas that helped to contain the spread of the virus, ended the pandemic through worldwide immunization, and after the crisis worked even more vigorously to make the world safer from future devastating pandemics. 


\section{References}

1. Johns Hopkins University \& Medicine, Coronavirus Resource Centers. Johns Hopkins Coronavirus Resource Center [Internet]. [cited 2020 Nov 8]. Available from: https://coronavirus.jhu.edu/

2. Gillet K, Magdziarz A, Pronczuk M, Novak B, Kramer AE. U.S. hits new coronavirus case record for third straight day. The New York Times [Internet]. 2020 Nov 9. [cited 2020 Nov 8]. Available from:

https://www.nytimes.com/live/2020/11/06/world/cov id-19-coronavirus-updates

3. Quick J. Coronavirus crisis update: Transcending pandemic denial, fatigue and anger [audio podcast]. [cited 2020 Dec14]. Available from: https://www.csis.org/podcasts/take-directedcoronavirus-crisis-update/coronavirus-crisis-updatedr-jonathan-jono-quick-\%E2\%80\%93

4. Meichtry S, Sugden J, Barnett A. Pandemic fatigue is real - and it's spreading. Wall Street Journal [Internet]. 2020 Oct 26. [cited 2020 Dec 14]. Available from:

https://www.wsj.com/articles/pandemic-fatigue-isrealand-its-spreading-11603704601

5. Aboagye D, Hamill S. It's time to fight Covid fatigue in Africa. The Mail \& Guardian [Internet]. 2020 Dec 8]. [cited 2020 Dec 14]. Available from: https://mg.co.za/africa/2020-12-08-its-time-to-fightcovid-fatigue-in-africa/

6. Carothers T, Press B. Amid the COVID-19

Pandemic, Protest Movements Challenge Lockdowns Worldwide. World Polit Rev [Internet] 2020 Oct 15. [cited 2020 Dec 14]. Available from: https://www.worldpoliticsreview.com/articles/29137/ amid-the-covid-19-pandemic-protest-movementschallenge-lockdowns-worldwide

7. Zimmer C, Corum J, Wee S-L. Coronavirus vaccine tracker. The New York Times [Internet]. 2020 Jun 10. [cited Dec 14]. Available from: https:/www.nytimes.com/interactive/2020/science/c oronavirus-vaccine-tracker.html.

8. Otto A. Cura personalis. Ignatian Spirituality [Internet]. 2013 Aug 15. [cited 2020 Nov 8]. Available from: https://www.ignatianspirituality.com/cura-personalis/

9. Georgetown University School of Medicine [Internet]. About cura personalis. [citied $2020 \mathrm{Nov}$

Dec 2020. Christian Journal for Global Health 7(5)
8]. Available from:

https://som.georgetown.edu/mission-andculture/cura-personalis/

10. Stark R. The rise of Christianity: How the obscure, marginal Jesus movement became the dominant religious force in the Western world in a few centuries. Princeton University Press; 1997.

11. Luther M. Whether One May Flee From A Deadly Plague [Internet]. 1527. [cited 2020 Dec 17].

Available from:

https://www.christianitytoday.com/ct/2020/mayweb-only/martin-luther-plague-pandemiccoronavirus-covid-flee-letter.html.

12. Flessa S. Christian milestones in global health: The Declarations of Tübingen. Christ J Glob Health. 2016;3(1):11-24. https://doi.org/10.15566/cjgh.v3i1.96

13. BioLogos - Resources [Internet]. A Christian response to coronavirus: A virtual event with N.T. Wright and Francis Collins. [cited 2020 Nov 8]. Available from: https://biologos.org/resources/achristian-response-to-coronavirus-a-podcastrecording-with-n-t-wright-and-francis-collins/

14. Wright NT. God and the pandemic: A Christian reflection on the coronavirus and its aftermath. Grand Rapids: Zondervan; 2020.

15. Collins FS. The language of God: A scientist presents evidence for belief. First Paperback Edition. New York: Free Press; 2007.

16. Wight P. Some faith leaders defiant, others transparent over COVID-19 outbreaks [audio]. NPR.org [Internet]. [cited 2020 Dec 14]. Available from: https://www.npr.org/2020/11/19/936490226/somefaith-leaders-defiant-others-transparent-over-covid19-outbreaks

17. James A, Eagle L, Phillips C, Hedges DS, Bodenhamer C, Brown R, Wheeler JG, Kirking H. High COVID-19 attack rate among attendees at events at a church — Arkansas, March 2020. MMWR Morb Mortal Wkly Rep. 2020 May 22;69(20):632-635. https://doi.org/10.15585/mmwr.mm6920e2

18. Mahale P, Rothfuss C, Bly S, et al. Multiple COVID-19 outbreaks linked to a wedding reception in rural Maine - August 7-September 14, 2020. MMWR Morb Mortal Wkly Rep. 2020;69(45):16861690. https://doi.org/10.15585/mmwr.mm6945a5 
19. Kim S, Jeong YD, Byun JH, et al. Evaluation of COVID-19 epidemic outbreak caused by temporal contact-increase in South Korea. Int J Infect Dis IJID Off Publ Int Soc Infect Dis. 2020;96:454-457. https://doi.org/10.1016/j.ijid.2020.05.036

20. Bailey SP. What NIH chief Francis Collins wants religious leaders to know about the coronavirus vaccines. Washington Post [Internet]. 2020 Dec 12. [cited 2020 Dec 14]. Available from: https://www.washingtonpost.com/religion/2020/12/1 2/coronavirus-vaccine-nih-francis-collins-faithleaders/

21. Lieberman A. Ties between UN, faith-based groups poised to grow during pandemic. Devex [Internet]. 2020 Oct 28. [cited 2020 Dec 17]. Available from: https://www.devex.com/news/sponsored/tiesbetween-un-faith-based-groups-poised-to-growduring-pandemic-98357

22. Xiong J (Jane), Isgandarova N, Panton AE. COVID19 Demands Theological Reflection: Buddhist, Muslim, and Christian Perspectives on the Present Pandemic. Int J Pract Theol. 2020;24(1):5-28. https://doi.org/10.1515/ijpt-2020-0039

23. Christian Connections for International Health [Internet]. Faith-based organizations and COVID-19. Accessed December 16, 2020. Available from: https://www.ccih.org/cpt resources/covid-19/

24. Scott S. Adapting to COVID-19 reality to continue other health services. CCIH [Internet]. 2020 Nov 20. [cited 2020 Dec 16. Available from: https://www.ccih.org/adapting-to-covid-19-realityto-continue-other-health-services/

25. Carty T. Navigating one crisis helped prepare for another: AMOS Health \& Hope responds to COVID19 in Nicaragua. CCIH [Internet]. 2020 July 17. [cited Dec 17]. Available from: https://www.ccih.org/navigating-one-crisis-helpedprepare-for-another-amos-health-hope-responds-tocovid-19-in-nicaragua/

26. Gavi [Internet]. COVAX explained. [cited 2020 Dec 17]. Available from: https://www.gavi.org/vaccineswork/covax-explained

27. Lancet Editorial. Global governance for COVID-19 vaccines. The Lancet. 2020;395(10241):1883. https://doi.org/10.1016/S0140-6736(20)31405-7

28. Marshall K, Seifman R. COVID-19 vaccines: Bridging religious divides, engaging religious support. Impakter [Internet]. 2020 Dec 10. [cited

Dec 2020. Christian Journal for Global Health 7(5)
2020 Dec 15]. Available from:

https://impakter.com/covid-vaccines-engagingreligious-support/

29. US News \& World Report [Internet].Poor should get Covid-19 vaccine first, Pope Francis says. 2020 Sept 25. [cited 2020 Dec 14]. Available from:

https://www.usnews.com/news/world/articles/202009-25/poor-should-get-covid-19-vaccine-first-popefrancis-says

30. Quick JD, Larson H. The vaccine-autism myth started 20 years ago. Here's why it endures today. Time. 28 Feb 2018. Available from: https://time.com/5175704/andrew-wakefieldvaccine-autism/

31. Grabenstein JD. What the World's religions teach, applied to vaccines and immune globulins. Vaccine. 2013;31(16):2011-2023. https://doi.org/10.1016/j.vaccine.2013.02.026

32. Lazarus JV, Ratzan SC, Palayew A, et al. A global survey of potential acceptance of a COVID-19 vaccine. Nat Med. 2020 Oct 20:1-4. https://doi.org/10.1038/s41591-020-1124-9

33. Funk $\mathrm{C}$, Tyson $\mathrm{A}$. Intent to get a COVID-19 vaccine rises to $60 \%$ as confidence in research and development process increases. 2020 Dec 3. [cited Dec 14]. Available from: https://www.pewresearch.org/science/2020/12/03/int ent-to-get-a-covid-19-vaccine-rises-to-60-asconfidence-in-research-and-development-processincreases/

34. Funk C, Gramlich J. Amid coronavirus threat, Americans generally have a high level of trust in medical doctors. Pew Research Center. 2020 Mar 13. [cited 2020 Dec 15]. Available from: https://www.pewresearch.org/facttank/2020/03/13/amid-coronavirus-threat-americansgenerally-have-a-high-level-of-trust-in-medicaldoctors/

35. Johns Hopkins Coronavirus Resource Center [Internet]. International Vaccine Access Center. Vaccines FAQ. [cited 2020 Dec 15]. Available from: https://coronavirus.jhu.edu/

36. Sokolow A. With science and scripture, a pastor fights Covid-19 vaccine skepticism. STAT. 2020 Aug 31. [cited 2020 Dec 14]. Available from: https://www.statnews.com/2020/08/31/with-scienceand-scripture-a-baltimore-pastor-is-fighting-covid19-vaccine-skepticism/ 
37. Warren RC, Forrow L, Hodge DA, Truog RD. Trustworthiness before trust - Covid-19 vaccine trials and the black community. N Engl J Med. 2020;383(22):e121. https://doi.org/10.1056/NEJMp2030033

38. Quick JD, Fryer B. The end of epidemics: The looming threat to humanity and how to stop it. St. Martin's Press/Macmillan; 2018.

39. Dobson AP, Pimm SL, Hannah L, et al. Ecology and economics for pandemic prevention. Science.
2020;369(6502):379-381.

https://doi.org/10.1126/science.abc3189

40. Quick JD. Our collective flu complacency is killing us. Time. 2018 Jan 19. [cited 2019 Sept 17].

Available from: https://time.com/5107964/flu-2018epidemic/

41. Quick JD, Heymann D. The end of epidemics: How to stop viruses and save humanity now. Scribe; 2020.

Submitted: 27 Nov 2020, accepted 15 Dec 2020, published 21 Dec 2020

Competing Interests: None declared.

Correspondence: Dr. Jonathan Quick, jonoquick7@gmail.com

Cite this article as: Quick JD. Cura personalis, Cura communitas: Loving our neighbor in Covid-19 times. Christ J Global Health. Aug 2020; 7(3):3-8. https://doi.org/10.15566/cigh.v7i3.495

(C) Author. This is an open-access article distributed under the terms of the Creative Commons Attribution License, which permits unrestricted use, distribution, and reproduction in any medium, provided the original author and source are properly cited. To view a copy of the license, visit http://creativecommons.org/licenses/by/4.0/ 